\title{
Flow Photocleavage for Automated Glycan Assembly (AGA)
}

\author{
Charlotte S. Teschers, Ryan Gilmour* \\ Organisch-Chemisches Institut, Westfälische Wilhelms-Universität Münster, Corrensstr. 40, 48149 Münster, \\ Germany.
}

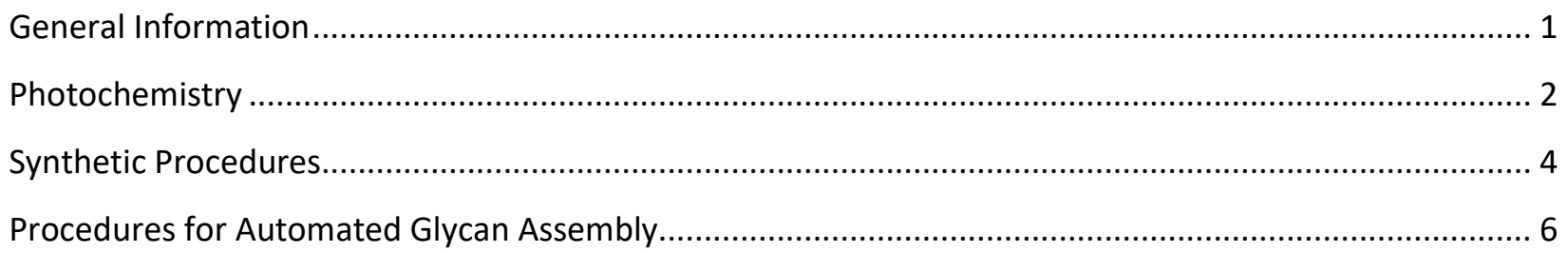




\section{GENERAL INFORMATION}

All chemicals were purchased as reagent grade and used without further purification. Solvents for purification (extraction and chromatography) were purchased as technical grade and distilled on the rotary evaporator prior to use. For column chromatography SiO2-(40-63 $\mu \mathrm{m}$ for flash chromatography, VWR Chemicals) was used as stationary phase. Analytical thin layer chromatography (TLC) was performed on aluminum foil pre-coated with SiO2-60 F254 (Merck) and visualized with a UV-lamp (254 nm) and CAM solution. Concentration in vacuo was performed at $\sim 10 \mathrm{mbar}$ and $40{ }^{\circ} \mathrm{C}$, drying at $\sim 10^{-2} \mathrm{mbar}$ and room temperature. NMR spectra were measured by the NMR service of the Organisch-Chemisches Institut, Westfälische Wilhelms-Universität Münster on a Bruker AV400 or an Agilent DD2 600 spectrometer at room temperature. The chemical shifts are referenced to the residual solvent peak as internal standard. The resonance multiplicity is abbreviated as: $s$ (singlet), $d$ (doublet), $t$ (triplet), q (quadruplet), $p$ (pentet), sext (sextet), sep (septet), $m$ (multiplet) and b (broad). Assignments of unknown compounds are based on DEPT, COSY, HMBC, HSQC and NOESY spectra. Melting points were measured on a Büchi B-545 meltingpoint apparatus in open capillaries. IR spectra were recorded on a Perkin-Elmer 100 FT-IR spectrometer, selected adsorption bands are reported in wavenumbers $\left(\mathrm{cm}^{-1}\right)$ and intensities are reported as: $w$ (weak), $\mathrm{m}$ (medium) and s (strong). High-resolution mass spectra (HR-ESI) were measured by the MS service of the Organisch-Chemisches Institut, Westfälische Wilhelms-Universität Münster. Optical rotation was measured on a Jasco P-2000 polarimeter. UV/vis absorption spectra were measured on an Agilent Cary 60 UV-Vis spectrophotometer, baseline correction was performed with the respective blank solutions. Batch photoreactions were performed with a UVA LED (365 nm, emission spectrum see Figure S1).

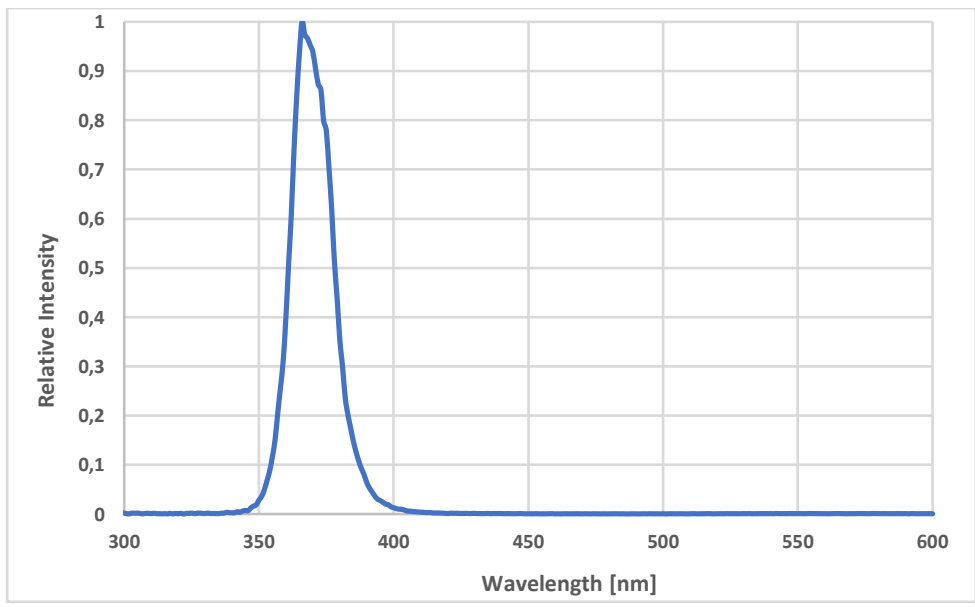

Figure S1. Emission spectrum of the UVA LED used for batch photoreactions. 


\section{PHOTOCHEMISTRY}

\section{Photoreactor}

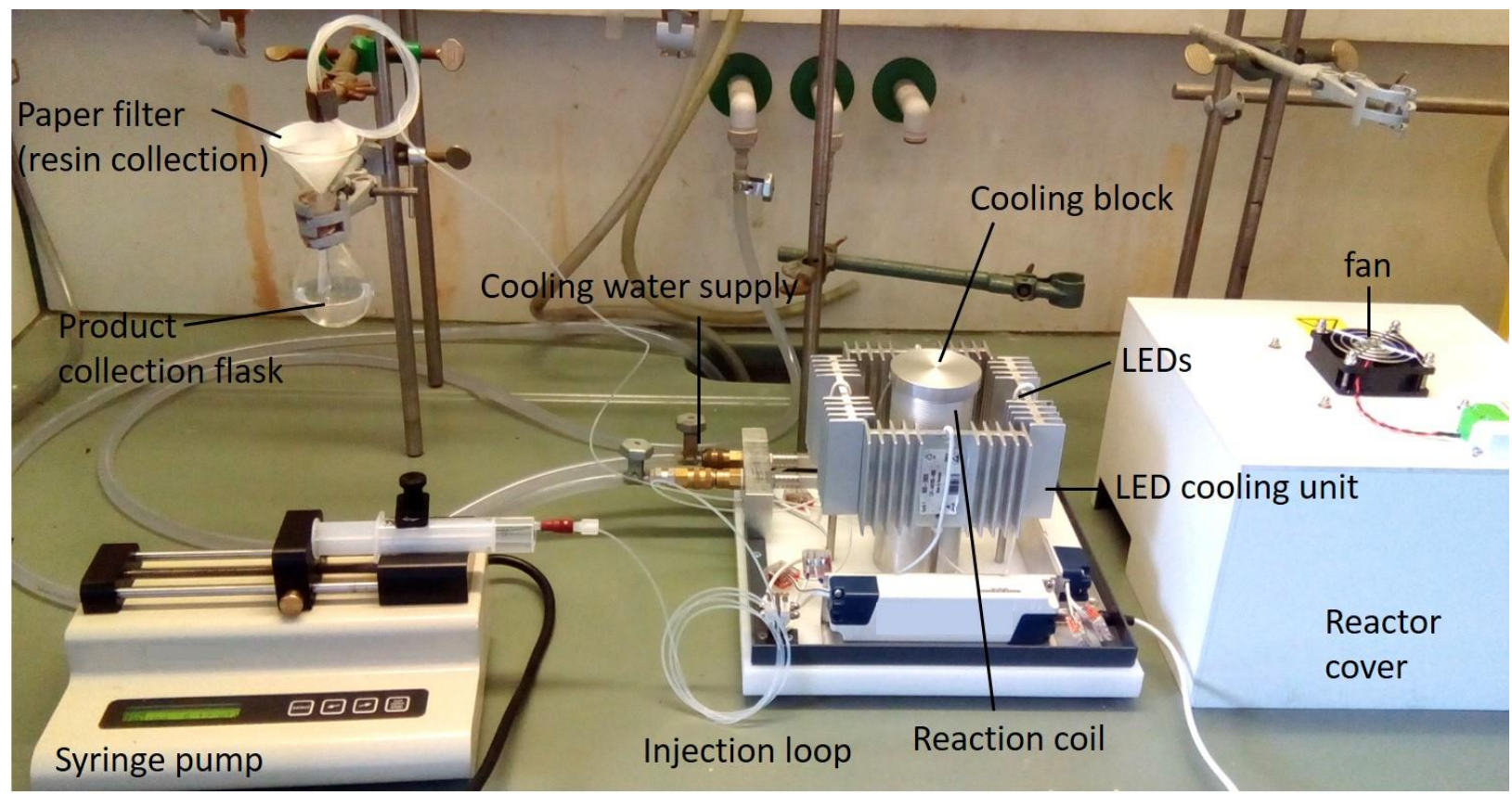

Figure S2. Setup for the continuous flow photocleavage. The reactor cover was removed to show the inside of the photoreactor, but needs to be closed during operation.

The photocleavage from solid support was performed in a custom-build $365 \mathrm{~nm}$ LED flow reactor (Figure S2). The photoreactor comprises eight LEDs (LED Engin LZ4-04UV00, 2000-3800 mW radiant flux @ $750 \mathrm{~mA}$ ), which are dimmed to $350 \mathrm{~mA}$. Aluminum cooling units were arranged in a square, and two LEDs stacked above each other ( $4 \mathrm{~cm}$ distance) were mounted in the middle of each cooling unit facing the inside of the square. The reaction coil is located inside the square with a distance of $3 \mathrm{~cm}$ to the LEDs. The reaction coil consists of transparent FEP tubing $(0.8 \mathrm{~mm}$ inner diameter) wrapped around a water-cooled aluminum cylinder. A thread is cut into the cooling block to maximize the contact area between cooling cylinder and FEP tubing. The total reactor volume is $6 \mathrm{~mL}(1 \mathrm{~mL}$ injection loop, $4 \mathrm{~mL}$ inside reactor, $1 \mathrm{~mL}$ outlet).

The reactor is covered with a non-transparent lid, which is required to push down a safety interlock switch to close the electric cycle for the LED power supply. The cover is further equipped with an electric fan to ventilate the reactor and secure temperature control of the LED cooling units. The fan is installed in a way that secures that no irradiation can escape the reactor.

The resin is pushed through the reactor using a Fisherbrand KDS 100 legacy syringe pump. The solid support is removed by simple filtration through a paper filter and the filtrate containing the target compound is collected in a round-bottom flask. 


\section{Photocleavage in Batch}

FPC-resin (ca. $30 \mathrm{mg}$ ) is placed in a $10 \mathrm{~mL}$ round-bottom flask at a distance of $1 \mathrm{~cm}$ from a $1 \mathrm{~W}$ UVA LED (365 nm). $\mathrm{CH}_{2} \mathrm{Cl}_{2}(3 \mathrm{~mL})$ is added and the mixture is stirred at $100 \mathrm{rpm}$ for 8 or $16 \mathrm{~h}$. The resin is filtered off, washed with $\mathrm{CH}_{2} \mathrm{Cl}_{2}$ and $\mathrm{MeOH}$ and collected for Fmoc quantification.

\section{General Procedure for the Photocleavage in Flow}

The reactor is initially rinsed with $15 \mathrm{~mL}$ of $\mathrm{CH}_{2} \mathrm{Cl}_{2}$ at a flow rate of $240 \mathrm{~mL} / \mathrm{h}$. 25-30 mL resin, swollen in 1$1.5 \mathrm{~mL}$ of $\mathrm{CH}_{2} \mathrm{Cl}_{2}$, is slowly injected from a $2 \mathrm{~mL}$ syringe into the FEP tubing. The resin is pushed through the reactor with $15 \mathrm{~mL}$ of $\mathrm{CH}_{2} \mathrm{Cl}_{2}$ at the specified flow rate. To shrink out the remaining resin, the reactor is rinsed with $\mathrm{CH}_{2} \mathrm{Cl}_{2} / \mathrm{MeOH}(1 / 1,7 \mathrm{~mL}$, specified flow rate; then $6 \mathrm{~mL}, 240 \mathrm{~mL} / \mathrm{h})$ and $\mathrm{MeOH}(10 \mathrm{~mL}$, $240 \mathrm{~mL} / \mathrm{h})$. Before the next injection, the reactor is re-equilibrated with $\mathrm{CH}_{2} \mathrm{Cl}_{2}(15 \mathrm{~mL}, 240 \mathrm{~mL} / \mathrm{h})$. Photocleavage yields and standard errors of the mean are reported in Table S1.

Table S1. Examining the efficiency of photocleavage from solid support using a continuous flow LED photoreactor: Varying number of cycles and flow rate.

\begin{tabular}{|c|c|c|c|c|}
\hline entry & flow rate $[\mathrm{mL} / \mathrm{h}]$ & cycles & yield [\%] & SEM [\%] \\
\hline 1 & 50 & 1 & 63 & \multirow{2}{*}{0.85} \\
\hline 2 & 50 & 1 & 65 & \\
\hline 3 & 36 & 1 & 68 & \multirow{2}{*}{0.84} \\
\hline 4 & 36 & 1 & 70 & \\
\hline 5 & 18 & 1 & 73 & \multirow{2}{*}{2.1} \\
\hline 6 & 18 & 1 & 77 & \\
\hline 7 & 9 & 1 & 74 & \multirow{2}{*}{0.26} \\
\hline 8 & 9 & 1 & 75 & \\
\hline 9 & 18 & 2 & 79 & \multirow{2}{*}{0.27} \\
\hline 10 & 18 & 2 & 80 & \\
\hline 11 & 9 & 2 & 78 & \multirow{2}{*}{0.25} \\
\hline 12 & 9 & 2 & 78 & \\
\hline $13^{a}$ & 18 & 1 & 81 & -- \\
\hline $14^{\mathrm{a}}$ & 18 & 2 & 86 & -- \\
\hline
\end{tabular}

\section{Determination of Fmoc Loading}

The resin loading was determined following a literature procedure. ${ }^{1}$ The functionalized resin was incubated with a stock solution of $2 \%$ DBU in DMF (v/v, $2 \mathrm{~mL})$ for $1 \mathrm{~h}$. A $160 \mu \mathrm{L}$ aliquot was transferred into a graduated $10 \mathrm{~mL}$ flask and diluted with acetonitrile. $4 \mathrm{~mL}$ of this solution were transferred into a quartz cuvette ( $1 \mathrm{~cm}$ diameter) and the UV absorption was measured in the range from 285-315 nm in $1 \mathrm{~nm}$ steps. The absorbance at 294 and $304 \mathrm{~nm}$ were used to calculate the Fmoc loading according to equations (1) 
and (2). The average of both values is reported. The photocleavage yield was calculated relative to nonirradiated FCP-resin. A blank solution was prepared in the same way without resin.

$$
\begin{aligned}
& \text { Fmoc loading }\left[\mathrm{mmol} * \mathrm{~g}^{-1}\right]_{294}=A b s_{294} * 14.2 / m_{\text {resin }}[\mathrm{mg}] \\
& \text { Fmoc loading }\left[\mathrm{mmol} * \mathrm{~g}^{-1}\right]_{304}=A b s_{304} * 16.3 / m_{\text {resin }}[\mathrm{mg}]
\end{aligned}
$$

\section{SYNTHETIC PROCEDURES}

\section{Synthesis of PC-resin ${ }^{2}$}

Merrifield resin $(18.01 \mathrm{~g}$, loading $0.45 \mathrm{mmol} / \mathrm{g}, 8.11 \mathrm{mmol})$ was suspended in $\mathrm{CH}_{2} \mathrm{Cl}_{2}(60 \mathrm{~mL})$ and gently shaken on a rotavap for $4 \mathrm{~h}$. The flask was covered in aluminum foil before a solution of 1 (3.778 g, $9.727 \mathrm{mmol}, 1.2$ eq.) in $\mathrm{CH}_{2} \mathrm{Cl}_{2}(10 \mathrm{~mL})$, DMF $(110 \mathrm{~mL}), \mathrm{Cs}_{2} \mathrm{CO}_{3}(3.962 \mathrm{~g}, 12.16 \mathrm{mmol}, 1.5 \mathrm{eq}$.) and TBAI ( $4.492 \mathrm{~g}, 12.16 \mathrm{mmol}, 1.5 \mathrm{eq}$.) were added. The mixture was stirred at $60^{\circ} \mathrm{C}$ and $200 \mathrm{mbar}$ on the rotavap overnight. The solution was drained and the resin was washed with $\mathrm{DMF} / \mathrm{H}_{2} \mathrm{O}(1 / 1), \mathrm{DMF}, \mathrm{MeOH}, \mathrm{CH}_{2} \mathrm{Cl}_{2}$, $\mathrm{MeOH}, \mathrm{CH}_{2} \mathrm{Cl}_{2}\left(6 \times 40 \mathrm{~mL}\right.$ each). The resin was swollen in $\mathrm{CH}_{2} \mathrm{Cl}_{2}$ for $2 \mathrm{~h}$ whereon DMF (130 mL) and CsOAc ( $3.112 \mathrm{~g}, 16.21 \mathrm{mmol}, 2.0$ eq.) were added. The mixture was stirred at $60^{\circ} \mathrm{C}$ and $200 \mathrm{mbar}$ on the rotavap overnight. The solution was drained and the resin was washed with $\mathrm{DMF} / \mathrm{H}_{2} \mathrm{O}(1 / 1), \mathrm{DMF}, \mathrm{MeOH}, \mathrm{CH}_{2} \mathrm{Cl}_{2}$, $\mathrm{MeOH}, \mathrm{CH}_{2} \mathrm{Cl}_{2}(6 \times 40 \mathrm{~mL}$ each) and dried in vacuo.

\section{Synthesis of FPC-resin ${ }^{2}$}

PC-resin (933 mg) was suspended in $\mathrm{CH}_{2} \mathrm{Cl}_{2}(10 \mathrm{~mL})$ in a flask covered in aluminum foil and gently shaken on a rotavap for $4 \mathrm{~h}$. A solution of Fmoc chloride $(579 \mathrm{mg}, 2.24 \mathrm{mmol}$, ca. 10 eq.) and pyridine $(0.6 \mathrm{~mL})$ in $\mathrm{CH}_{2} \mathrm{Cl}_{2}(15 \mathrm{~mL}$ ) was added and the mixture was stirred on the rotavap overnight. The resin was filtered off, washed with $\mathrm{CH}_{2} \mathrm{Cl}_{2}, \mathrm{MeOH}, \mathrm{CH}_{2} \mathrm{Cl}_{2}, \mathrm{MeOH}(5 \times 10 \mathrm{~mL}$ each) and dried in vacuo.

\section{Synthesis of Mannose Building Block 3}

\section{4-Methylphenyl 2-O-benzoyl-3,4-di-O-benzyl-1-thio- $\alpha$-D-mannopyranoside $S 1^{3,4}$}

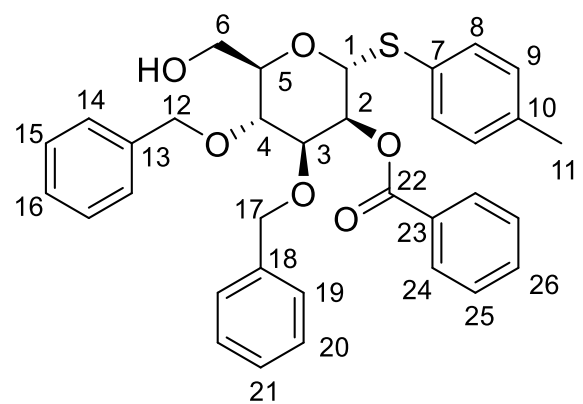

21

Benzoyl chloride ( $3.34 \mathrm{~mL}, 29.0 \mathrm{mmol}, 2.2$ eq.) was added to a solution of 4-methylphenyl 3-O-benzyl-4,6-O-benzylidene-1-thio$\alpha$-D-mannopyranoside ${ }^{3}(6.127 \mathrm{~g}, 13.19 \mathrm{mmol}, 1.0$ eq.) and TMEDA (1.19 mL, $7.91 \mathrm{mmol}, 0.6$ eq.) in dry $\mathrm{CH}_{2} \mathrm{Cl}_{2}(100 \mathrm{~mL})$ at $0{ }^{\circ} \mathrm{C}$ under argon. The reaction mixture was allowed to warm to room temperature while stirring overnight $(21 \mathrm{~h})$. The reaction was quenched with aqueous $\mathrm{HCl}(0.5 \mathrm{~m})$, the aqueous layer was extracted with $\mathrm{CH}_{2} \mathrm{Cl}_{2}(3 \times 30 \mathrm{~mL})$ and washed with brine. The

combined organic layers were dried over $\mathrm{MgSO}_{4}$ and the solvent was removed in vacuo. The residue was dissolved in dry $\mathrm{CH}_{2} \mathrm{Cl}_{2}(100 \mathrm{~mL})$ and cooled to $-5^{\circ} \mathrm{C}$, whereon borane $(1 \mathrm{M}$ in THF, $39.5 \mathrm{~mL}, 39.5 \mathrm{mmol}$, 3.0 eq.) and TMSOTf ( $715 \mu \mathrm{L}, 3.96 \mathrm{mmol}, 0.3$ eq.) were added successively. The mixture was stirred at $0{ }^{\circ} \mathrm{C}$ overnight $(17 \mathrm{~h})$ and was carefully quenched with $\mathrm{NEt}_{3}(1.5 \mathrm{~mL})$ and $\mathrm{MeOH}(2.5 \mathrm{~mL})$. The reaction mixture 
was concentrated in vacuo, loaded onto $\mathrm{SiO}_{2}$ and purified by column chromatography $\left(\mathrm{SiO}_{2}, \mathrm{CyH} / \mathrm{EtOAc}\right.$ 9/1) to give $\mathbf{S} 1$ as a colorless semi-solid (6.503 g, $11.39 \mathrm{mmol}, 86 \%)$.

$[\alpha]_{\mathrm{D}}^{22} 71.4\left(\mathrm{c}=1.0, \mathrm{CHCl}_{3}\right)$.

${ }^{1} \mathrm{H}$ NMR $\left(599 \mathrm{MHz}, \mathrm{CCDCl}_{3}\right) \delta 8.08-8.05(\mathrm{~m}, 2 \mathrm{H}, \mathrm{H}-\mathrm{C} 24), 7.62-7.57(\mathrm{~m}, 1 \mathrm{H}, \mathrm{H}-\mathrm{C} 26), 7.49-7.45(\mathrm{~m}, 2 \mathrm{H}$, $\mathrm{H}-\mathrm{C} 25), 7.39-7.36$ (m, 2H, H-C8), $7.36-7.26$ (m, 10H, H-C14/15/16/19/20/21), $7.14-7.11$ (m, 2H, H-C9), $5.84(\mathrm{dd}, J=2.9,1.8 \mathrm{~Hz}, 1 \mathrm{H}, \mathrm{H}-\mathrm{C} 2), 5.52(\mathrm{~d}, J=1.7 \mathrm{~Hz}, 1 \mathrm{H}, \mathrm{H}-\mathrm{C} 1), 4.95$ (d, J=10.9 Hz, 1H, H-C12), 4.81 (d, $J=11.4 \mathrm{~Hz}, 1 \mathrm{H}, \mathrm{H}-\mathrm{C} 17), 4.69$ (d, J = 11.0 Hz, 1H, H-C12), 4.62 (d, J = 11.4 Hz, 1H, H-C17), 4.27 (ddd, J = 9.4, 3.9, $2.8 \mathrm{~Hz}, 1 \mathrm{H}, \mathrm{H}-\mathrm{C} 5$ ), 4.09 (dd, J= 9.3, $2.9 \mathrm{~Hz}, 1 \mathrm{H}, \mathrm{H}-\mathrm{C} 3$ ), 4.05 (t, J = 9.3 Hz, 1H, H-C4), 3.88 (dd, J = 11.9, $2.8 \mathrm{~Hz}, 1 \mathrm{H}, \mathrm{H}-\mathrm{C} 6), 3.84$ (dd, J = 11.9, $4.0 \mathrm{~Hz}, 1 \mathrm{H}, \mathrm{H}-\mathrm{C} 6), 2.33$ (s, 3H, H-C11) ppm.

HRMS (ESI) m/z [M+Na] ${ }^{+}$calcd for $\mathrm{C}_{34} \mathrm{H}_{34} \mathrm{O}_{6} \mathrm{SNa} 593.19683$; found 593.19691.

The spectroscopic data are in agreement with the literature. ${ }^{5}$

4-Methylphenyl mannopyranoside (3)

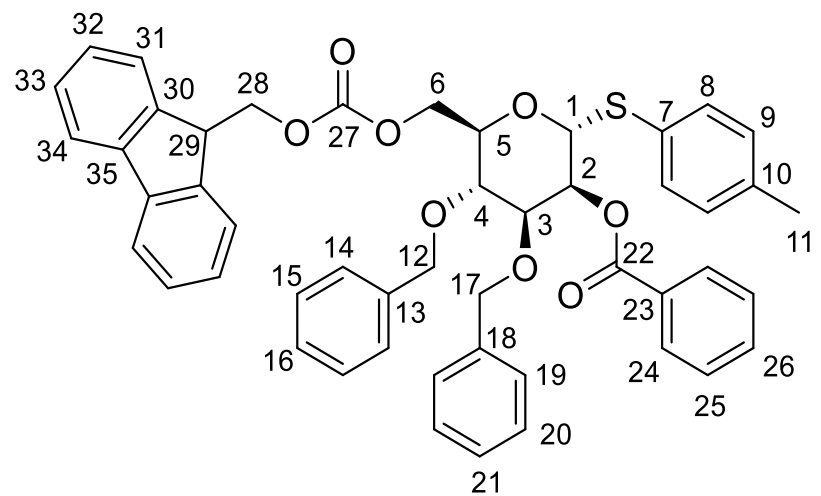

Fmoc chloride $(1.01 \mathrm{~g}, 3.89 \mathrm{mmol}, 1.2$ eq.) was added to a solution of $\mathbf{S 1}(1.849 \mathrm{~g}, 3.240 \mathrm{mmol}$, 1.0 eq.) and TMEDA ( $292 \mu \mathrm{L}, 1.94 \mathrm{mmol}, 0.6$ eq.) in dry $\mathrm{CH}_{2} \mathrm{Cl}_{2}(60 \mathrm{~mL})$ at $0{ }^{\circ} \mathrm{C}$ under argon. The solution was allowed to gradually warm to $\mathrm{rt}$ overnight (17 h). The reaction was quenched with aqueous $\mathrm{NaH}_{2} \mathrm{PO}_{4}$ and the aqueous layer was extracted with $\mathrm{CH}_{2} \mathrm{Cl}_{2}(3 \times 20 \mathrm{~mL})$. The combined organic layers were washed with brine, dried over $\mathrm{MgSO}_{4}$ and concentrated in vacuo. The crude product was purified by column chromatography $\left(\mathrm{SiO}_{2}, \mathrm{CyH} \rightarrow 3 \% \mathrm{EtOAc}\right)$ to give thiodonor 3 as a solid white foam (2.194 g, $2.767 \mathrm{mmol}, 85 \%)$.

m.p. $52^{\circ} \mathrm{C}$.

$[\alpha]_{\mathrm{D}}^{22} 59.6\left(\mathrm{c}=1.0, \mathrm{CHCl}_{3}\right)$.

${ }^{1} \mathrm{H}$ NMR $\left(599 \mathrm{MHz}, \mathrm{CDCl}_{3}\right) \delta 8.14-8.09(\mathrm{~m}, 2 \mathrm{H}, \mathrm{H}-\mathrm{C} 24), 7.78(\mathrm{dt}, J=7.6,1.0 \mathrm{~Hz}, 2 \mathrm{H}, \mathrm{H}-\mathrm{C} 34), 7.65(\mathrm{dd}, J=$ 7.6, $1.3 \mathrm{~Hz}, 1 \mathrm{H}, \mathrm{H}-\mathrm{C} 31), 7.62$ (dd, J = 7.6, 1.0 Hz, 1H, H-C31), $7.56-7.50(\mathrm{~m}, 1 \mathrm{H}, \mathrm{H}-\mathrm{C} 26), 7.45-7.38(\mathrm{~m}, 8 \mathrm{H}$, $\mathrm{H}-\mathrm{C} 8 / 20 / 25 / 33$ ), $7.37-7.26$ (m, 10H, H-C14/15/16/19/21/32), 7.10 (d, J = 7.8 Hz, 2H, H-C9), $5.90-5.88$ (m, 1H, H-C2), 5.55 (d, J = 1.7 Hz, 1H, H-C1), 4.97 (d, J = 10.9 Hz, 1H, H-C12), 4.84 (d, J = 11.3 Hz, 1H, H-C17), 4.66 (d, J = 10.9 Hz, 1H, H-C12), 4.63 (d, J = 11.3 Hz, 1H, H-C17), $4.55-4.51$ (m, 1H,H-C5), $4.51-4.49$ (m, $2 \mathrm{H}, \mathrm{H}-\mathrm{C} 6$ ), 4.42 (dd, J=10.5, 7.6 Hz, 1H, H-C28), 4.38 (dd, J=10.5, 7.5 Hz, 1H, H-C28), 4.26 (t, J= 7.6 Hz, $1 \mathrm{H}, \mathrm{H}-\mathrm{C} 29), 4.11$ (dd, J = 9.2, 3.1 Hz, 1H, H-C3), 4.04 (t, J = 9.4 Hz, 1H, H-C4), 2.29 (s, 3H, H-C11) ppm.

${ }^{13} \mathrm{C}$ NMR (151 MHz, CDCl $)$ ) $\delta 165.7$ (C22), 155.3 (C27), 143.6/143.4 (C30), 141.4 (C35), 138.4 (C10), 138.0 (C13), 137.6 (C18), 133.5 (C26), 132.9 (C33), 130.08 (C9), 130.06 (C24), 129.9 (C23), 129.6 (C7), 128.62 (C8), 
128.59 (C15/20), 128.4 (C14/19), 128.1 (C25), 128.0 (C16/21), 127.4/127.3 (C32), 125.4/125.3 (C31), 120.2

(C34), 86.9 (C1), 78.7 (C3), 75.4 (12), 74.2 (C4), 71.8 (C17), 70.8 (C5), 70.5 (C2), 70.2 (C28), 67.0 (C6), 46.9 (C29), 21.3 (C11) ppm.

IR (neat) v $3030.50(w), 2876.08(w), 1746.20(m), 1720.77(m), 1602.05(w), 1584.86(w), 1493.53(w)$, $1450.71(\mathrm{~m}), 1394.52(\mathrm{w}), 1317.11(\mathrm{w}), 1251.75(\mathrm{~s}), 1177.16(\mathrm{w}), 1088.40(\mathrm{~s}), 1027.18(\mathrm{~m}), 962.90(\mathrm{~m})$, $913.77(w), 858.71(w), 810.35(w), 784.24(m), 757.94(m), 738.44(s), 709.55(s), 697.30(s) \mathrm{cm}^{-1}$.

HRMS (ESI) $\mathrm{m} / \mathrm{z}[\mathrm{M}+\mathrm{Na}]^{+}$calcd for $\mathrm{C}_{49} \mathrm{H}_{44} \mathrm{O}_{8} \mathrm{SNa}$ 815.26491; found 815.26563.

\section{PROCEDURES FOR AUTOMATED GLYCAN ASSEMBLY}

Mannose building block 2 was coupled to PC-resin using the automated glycosylation platform glyconeer 2.1. PC-resin ( $52.4 \mathrm{mg}$, loading $0.24 \mathrm{mmol} / \mathrm{g}$ ) was swollen, washed and glycosylated using standard cycles controlled by the GlycoSoft software. After a capping cycle to terminate deletion sequences, the temporary Fmoc protecting group was removed and the glycosylation was repeated to furnish the desired disaccharide. The Fmoc group was not removed from the non-reducing end in order to quantify the photocleavage efficiency by Fmoc loading. Brief descriptions and relevant parameters for the automated modules (default parameters applied in all cases) are reported in the following. The synthesis comprised the modules in the order 1-2-3-4-5-2-3-4-6.

Module 1: Resin swelling. The resin was swollen in $\mathrm{CH}_{2} \mathrm{Cl}_{2}(1 \mathrm{~mL})$ for $30 \mathrm{~min}$ and the solvent was drained. The resin was washed with DMF, THF and $\mathrm{CH}_{2} \mathrm{Cl}_{2}$ ( $3 \times 1 \mathrm{~mL}$ for $25 \mathrm{~s}$ each).

Module 2: Acidic wash. The resin was washed with a solution of TMSOTf in $\mathrm{CH}_{2} \mathrm{Cl}_{2}$ (1 mL, $450 \mu \mathrm{L}$ TMSOTf in $40 \mathrm{~mL}$ anhydrous $\left.\mathrm{CH}_{2} \mathrm{Cl}_{2}\right)$ diluted with $\mathrm{CH}_{2} \mathrm{Cl}_{2}(1 \mathrm{~mL})$ at $-20^{\circ} \mathrm{C}$ for $5 \mathrm{~min}$. The solution was drained and the resin was washed with $\mathrm{CH}_{2} \mathrm{Cl}_{2}(1 \mathrm{~mL})$. The acid wash was repeated a second time.

Module 3: Glycosylation with 2. The resin was incubated in $\mathrm{CH}_{2} \mathrm{Cl}_{2}(1 \mathrm{~mL})$ until the temperature was adjusted to $0{ }^{\circ} \mathrm{C}$. Building block 2, dissolved in $\mathrm{CH}_{2} \mathrm{Cl}_{2}(1 \mathrm{~mL})$, and a solution of NIS and TfOH in $\mathrm{CH}_{2} \mathrm{Cl}_{2}$ (1.35 g NIS, $110 \mu \mathrm{L} \mathrm{TfOH} \mathrm{in} 40 \mathrm{~mL}$ dry $\mathrm{CH}_{2} \mathrm{Cl}_{2}, 1 \mathrm{~mL}$ ) were added successively. The mixture was incubated at $0{ }^{\circ} \mathrm{C}$ for $5 \mathrm{~min}$ before being warmed to $20^{\circ} \mathrm{C}$ (incubation $20 \mathrm{~min}$ ). The solution was drained and the resin washed with $\mathrm{CH}_{2} \mathrm{Cl}_{2} / 1$,4-dioxane (1/1) and $\mathrm{CH}_{2} \mathrm{Cl}_{2}(2 \times 1 \mathrm{~mL}$ for $25 \mathrm{~s}$ each).

Module 4: Acidic capping. The temperature was set to $25^{\circ} \mathrm{C}$ and the resin was washed with DMF ( $\left.3 \times 1 \mathrm{~mL}\right)$. The resin was washed with pyridine (10\% in DMF, $2 \mathrm{~mL}$ for $15 \mathrm{~s}$ ) and $\mathrm{CH}_{2} \mathrm{Cl}_{2}$ ( $3 \times 1 \mathrm{~mL}$ for $25 \mathrm{~s}$ ). A solution of $10 \% \mathrm{Ac}_{2} \mathrm{O}$ and $2 \% \mathrm{MsOH}$ in $\mathrm{CH}_{2} \mathrm{Cl}_{2}(2 \mathrm{~mL})$ was added and the resin incubated for $20 \mathrm{~min}$. The solution was drained and the resin was washed with $\mathrm{CH}_{2} \mathrm{Cl}_{2}(1 \mathrm{~mL})$.

Module 5: Fmoc deprotection. The resin was washed with DMF ( $3 \times 2 \mathrm{~mL}$ for $60 \mathrm{~s})$. Piperidine (20\% in DMF, $2 \mathrm{~mL}$ ) was added and the solution was drained through the UV detector unit after $5 \mathrm{~min}$. The absorbance was measured at $301 \mathrm{~nm}$ to monitor reaction progress. The resin was washed with DMF ( $3 \times 2 \mathrm{ml}$ for $60 \mathrm{~s})$ and the reaction vessel was filled with DMF $(15 \mathrm{~mL})$ to remove all residual base. The resin was washed with $\mathrm{CH}_{2} \mathrm{Cl}_{2}(5 \times 2 \mathrm{~mL}$ for $60 \mathrm{~s})$. 
Module 6: End wash. Rinses/purges the instrument for $20 \mathrm{~min}$.

The resin was removed from the reaction vessel, swollen in $\mathrm{CH}_{2} \mathrm{Cl}_{2}(1.5 \mathrm{~mL})$ in a $2 \mathrm{~mL}$ syringe and injected into the LED flow reactor. Photocleavage was performed following the general procedure for photocleavage in flow with a flow rate of $18 \mathrm{~mL} / \mathrm{h}$ and two irradiation cycles. The resin was filtered off and the yield determined by Fmoc quantification. The filtrate was concentrated in vacuo to give the crude disaccharide (14.1 mg, $10.4 \mu \mathrm{mol}, 83 \%$ ) as a colorless syrup.

${ }^{1} \mathbf{H}$ NMR $\left(400 \mathrm{MHz}, \mathrm{CDCl}_{3}\right) \delta 8.15-8.09(\mathrm{~m}, 4 \mathrm{H}), 7.76(\mathrm{~d}, J=7.6 \mathrm{~Hz}, 2 \mathrm{H}), 7.60$ (dd, J=11.6, 7.5 Hz, 2H), 7.55 $-7.45(\mathrm{~m}, 4 \mathrm{H}), 7.43-7.09(\mathrm{~m}, 31 \mathrm{H}), 5.79-5.74(\mathrm{~m}, 1 \mathrm{H}), 5.63(\mathrm{dd}, J=3.3,1.8 \mathrm{~Hz}, 1 \mathrm{H}), 5.13(\mathrm{~d}, J=1.9 \mathrm{~Hz}$, 1H), $5.08(\mathrm{~s}, 1 \mathrm{H}), 4.92(\mathrm{~d}, J=7.8 \mathrm{~Hz}, 1 \mathrm{H}), 4.88(\mathrm{~d}, J=11.8 \mathrm{~Hz}, 2 \mathrm{H}), 4.83(\mathrm{~d}, J=11.0 \mathrm{~Hz}, 1 \mathrm{H}), 4.77(\mathrm{~d}, J=11.3$ $\mathrm{Hz}, 1 \mathrm{H}), 4.59(\mathrm{~d}, J=11.0 \mathrm{~Hz}, 1 \mathrm{H}), 4.56(\mathrm{~d}, J=10.8 \mathrm{~Hz}, 1 \mathrm{H}), 4.49(\mathrm{~d}, J=11.2 \mathrm{~Hz}, 1 \mathrm{H}), 4.47(\mathrm{~d}, J=11.2 \mathrm{~Hz}, 1 \mathrm{H})$, $4.40-4.32(\mathrm{~m}, 4 \mathrm{H}), 4.22(\mathrm{t}, J=7.5 \mathrm{~Hz}, 1 \mathrm{H}), 4.11(\mathrm{t}, J=8.0 \mathrm{~Hz}, 1 \mathrm{H}), 4.10(\mathrm{t}, J=8.2 \mathrm{~Hz}, 1 \mathrm{H}), 4.02-3.95(\mathrm{~m}$, $2 \mathrm{H}), 3.93-3.83(\mathrm{~m}, 3 \mathrm{H}), 3.81(\mathrm{~d}, J=11.1 \mathrm{~Hz}, 1 \mathrm{H}), 3.70-3.62(\mathrm{~m}, 1 \mathrm{H}), 3.45-3.37(\mathrm{~m}, 1 \mathrm{H}), 3.22-3.13(\mathrm{~m}$, $2 \mathrm{H}), 1.63-1.28(\mathrm{~m}, 6 \mathrm{H})$. The spectroscopic data are in good agreement with the literature. ${ }^{6}$

\section{REFERENCES}

(1) Gude, M.; Ryf, J.; White, P. D. An accurate method for the quantitation of Fmoc-derivatized solid phase supports. Lett. Pept. Sci. 2002, 9, 203-206.

(2) Eller, S.; Collot, M.; Yin, J.; Hahm, H. S.; Seeberger, P. H. Automated solid-phase synthesis of chondroitin sulfate glycosaminoglycans. Angew. Chem. Int. Ed. 2013, 52, 5858-5861.

(3) Patil, P. S.; Lee, C.-C.; Huang, Y.-W.; Zulueta, M. M. L.; Hung, S.-C. Regioselective and stereoselective benzylidene installation and one-pot protection of D-mannose. Org. Biomol. Chem. 2013, 11, 2605-2612.

(4) Sano, T. Remarkably Fast Acylation of Alcohols with Benzoyl Chloride Promoted by TMEDA. Synthesis 1999, 1999, 1141-1144.

(5) Lin, Y. H.; Ghosh, B.; Mong, K.-K. T. In situ formation of $\beta$-glycosyl imidinium triflate from participating thioglycosyl donors: elaboration to disarmed-armed iterative glycosylation. Chem. Commun. 2012, 48, 10910-10912.

(6) Bakhatan, Y.; Alshanski, I.; Grunhaus, D.; Hurevich, M. The breaking beads approach for photocleavage from solid support. Org. Biomol. Chem. [Online early access]. DOI: 10.1039/d0ob00821d. 